\title{
Assessing Consequences of Component Sharing Across Brands in the Vertical
}

\section{Product Line in the Automotive Market}

\author{
Peter C. Verhoef ${ }^{1}$ \\ Faculty Economics and Business \\ University of Groningen \\ Koen H. Pauwels ${ }^{2}$ \\ Ozyegin University, Istanbul \\ Mirjam A. Tuk ${ }^{3}$ \\ Department of Marketing Communication \& Consumer Psychology \\ University of Twente \\ June $18,2014^{4}$
}

\footnotetext{
${ }^{1}$ Peter C. Verhoef, Professor of Marketing, University of Groningen, Faculty of Economics and Business, Department of Marketing, Office WNS 331, P.O. Box 800, 9700 AV Groningen, Tel. +3 50363 7320, e-mail: p.c.verhoef@rug.nl

${ }^{2}$ Professor of Marketing, Ozyegin University, Kuşbakışı Str. No:2, 34662 Altunizade Üsküdar İstanbul, email: koen.pauwels@ozyegin.edu.tr.

3 Assistant Professor, University of Twente, Department of Marketing Communication \& Consumer Psychology, Tel. +31 53489 2046, e-mail: m.a.tuk@utwente.nl

${ }^{4}$ The authors thank Kevin Keller, Stijn van Osselaer, the Marketing Science Institute and conference participants at the Tuck School of Business for helpful comments. They acknowledge the financial support of Zyman Institute for Brand Science (ZIBS) Emory University and the Customer Insights Center of the University of Groningen. They gratefully acknowledge Philip Hans Franses for sharing the sales data on the studied brands in study 2. They thank an anonymous reviewer for helpful comments on a prior version of the manuscript.
} 


\title{
Assessing Consequences of Component Sharing Across Brands in the Vertical Product Line in the Automotive Market
}

\begin{abstract}
Component sharing may look great in the boardroom, but not in the showroom. Indeed, savings on $\mathrm{R} \& \mathrm{D}$ and production costs could be offset by a plunge in customer brand attractiveness. Combining experimental with econometric studies, this paper investigates the impact of component sharing on customer evaluation of luxury, volume and economy brands offered in a car manufacturer's vertical product line. An experimental study shows that the evaluation of luxury brands sharing with a volume brand suffers more than when a volume brand shares components with an economy brand. The evaluation of an economy brand benefits more from sharing with a volume brand than a volume brand suffers from sharing with an economy brand. The magnitude of these effects depends on several factors, such as component type, the source of the component sharing and the salience of component sharing to the consumers. The explorative examination of market share effects confirms that luxury brands may suffer, while economy brands may benefit from component sharing. The first to look at the consumer impact of component sharing, this paper sets up a rich agenda for future research.
\end{abstract}

Key-words: Component sharing, branding, interface marketing and production, brand portfolio, ingredient branding, brand equity 


\section{Introduction}

Firms in different industries have adopted product-based strategies seeking product designs that allow high variety in the market place while simplifying the production and distribution system with a relatively low level of component variety and assembly complexity (Fisher, Ramdas, and Ulrich, 1999). Component sharing is an example of such product-based strategy. In component sharing, families of products have similar components. It is applied in many industries, including automobiles, computer hardware and consumer electronics (Desai, Kekre, Radhakrishnan, and Srinivasan, 2001; Moore, Louviere, and Verma, 1999). The automotive industry is particularly known for its use of component sharing, as new products drive firm profitability and stock market value (Pauwels, Silva-Risso, Srinivasan, and Hanssens, 2004), but are very costly to develop: from up to $\$ 100$ million in the late 1950 s to over $\$ 4$ billion in recent years (Sherman and Hoffer, 1971; White, 2001). The supply advantages of component sharing are twofold: leveraging high $\mathrm{R} \& \mathrm{D}$ costs over multiple products and achieving production efficiencies.

Two research streams have shed light on parts of our topic. Management science literature demonstrated the cost efficiency of component sharing practices in the automotive industry (Fisher et al., 1999) and discussed the appropriateness and optimal level of component sharing (Desai et al., 2001; Krishnan and Gupta, 2001; Ramdas and Sawhney, 2001). These studies do not directly examine consumer perceptions and evaluation and sales effects of component sharing. Second, the branding literature has investigated how brand- and line extensions and ingredient branding impact consumer brand evaluations (e.g., Desai and Keller, 2002, Echambi, Arroniz, Reinartz, and Lee, 2006; Loken and John, 1993; Park, Jun, and Shocker 1996, Simonin 
and Ruth, 1998, Völckner and Sattler, 2006; 2007), but remains silent about the precise impact of component sharing. In general, these studies show that such branding practices can have positive and negative effects on brand evaluations depending on the execution of the branding strategy.

From a managerial point of view, the impact of component sharing on brand evaluation is an important question. As component sharing has become common practice in many industries, consumers have start noticing (e.g. Financial Times, 2004; De Tijd, 2004; White, 2004). In a prestudy we indeed found that $93 \%$ of the surveyed 128 Dutch car buyers were aware of the fact that car producers commonly share components between brands. Hence, manufacturers cannot simply trust that their component sharing practices will remain a secret for all but the savviest consumers. Kerwin (2004) made this point clear in Business Week: "While sharing the basic structure of a car or truck can generate huge savings for most models, Ford discovered that it just won't wash in the luxury market. Most car buyers have no idea what a platform even is. But word quickly gets around when a new model shares its undercarriage with more plebeian cars. And it turns out that someone paying $\$ 40.000$ for the luxury cachet of his first Jaguar cares a great deal that car's guts are being shared with something that may cost only $\$ 20.000$ or so" (p. 72-73).

The above quote suggests that component-sharing practices impact customer evaluations for both sharing brands, which impact subsequent purchase behavior and prices paid for the car. However, systematic evidence on these effects is completely lacking. Does it really hurt luxury brands sharing components with volume brands (i.e. Jaguar sharing with Ford or Audi with Volkswagen), and does it benefit economy brands sharing components with a volume brand (i.e. Skoda with Volkswagen)? Do these effects differ between type of sourcing (e.g. what is the source of the component) and the type of components? And, how does it affect their brand 
market shares? In this study we aim to provide answers to these questions. First, we assess the potential brand evaluation consequences by using an experimental study manipulating brand combinations (luxury with volume and volume with economy), sourcing (higher positioned (higher-end) brand to a lower (lower-end) positioned brand, lower positioned brand to higher positioned brand or no specific source) and component type in an experiment where we make component sharing salient to consumers. Second, we explore the actual marketplace effects of component sharing practices by regressing market shares on price and product characteristics for brands in the vertical product line of the Volkswagen group (Audi, Volkwagen, Skoda and Seat).

The outline of this paper is as follows. First, we elaborate on how component sharing differs from other branding strategies such as brand extensions and ingredient branding. Next, we discuss relevant theory. Sections 4 and 5 discuss the setup and results of study 1 (experiment) and 2 (market share analysis). We conclude with theoretical managerial implications, study limitations and avenues for further research.

\section{Component sharing and branding strategies in the horizontal and vertical product line}

A firm's product line or portfolio can be characterized by its horizontal and vertical structure. The horizontal structure refers to the firms' activities in different product categories. Research on brand extensions has focused on this horizontal structure (e.g. Keller and Aaker, 1992). The focus of our study instead is the vertical product line (Randall, Ulrich, and Reibstein, 1998). In today's markets, firms offer different brands along the vertical product line with three general positioning strategies: 1) luxury (prestige, premium) brands, 2) volume (mass-market) brands, and 3) economy (price) brands. For instance, Volkswagen AG offers Audi (luxury), Volkswagen 
(volume) and Skoda (economy) in the car market. Firms have started to share components among the offered brands in the vertical product line (Fisher, Ramdas, and Ulrich, 1999).

Component sharing can be considered as a specific form of ingredient branding (Park et al., 1996; Simonin and Ruth, 1998; Venkatesh and Mahajan, 1997). In ingredient branding, a brand (e.g. Compaq or Godiva) explicitly communicates that one single attribute from the product is from a specific manufacturer (e.g. Intel or Slim Fast). Ingredient branding concerns two different brands operating in different though related product categories (i.e. computers and chips or washing powder and soap). Usually, the host branded product consists of many ingredients or components of which one ingredient is branded by a supplier from outside the product category. This ingredient branding is explicitly communicated to consumers, as it may distinguish them from other products (i.e. Godiva chocolate in Icecream).

The specific nature of component sharing is, that although the ingredient (i.e. shock absorber) is from another though related category, its source is not a brand from the other category, but is a brand within the same category. This brand is usually part of the vertical product line of the same manufacturer. Another difference is that component sharing is usually not explicitly communicated to consumers, while ingredient branding (i.e. Intel inside) is usually explicitly communicated. This may make component sharing less salient to consumers. Thus, while we can build on ingredient brand literature, the impact of component sharing requires further analysis.

\section{Theory}

\section{Effect of Component Sharing on Brand Evaluations}

The general expectation underlying our model is that component sharing across brands in the vertical product line will negatively affect brand evaluations of higher positioned brands (e.g. 
Park et al., 1996; Simonin and Ruth, 1998). Several behavioral theories support this assumption. The branding literature suggests that brands can be understood in terms of a set of attributes, each at particular performance levels (Keller, 1998). As components are shared, some attributes of the sharing brands become more alike. Hence, the differentiation between sharing brands decreases (Desai et al., 2001), especially if this differentiation is based on attributes that can be traced back to the shared components. Likewise, the economic value of a product to the customer consists of the reference value and the differentiation value (Nagle and Holden, 1995). Lower brand differentiation decreases the brands' uniqueness, which may decrease customer valuation of higher-end brands. Moreover, consumer research suggests that price differences across brands are frequently interpreted in terms of quality differences (Bolton, Warlop, and Alba, 2003). When components are shared, the perceived quality differences between brands shrink. Consequently, consumers may question the fairness of the price difference between a higher positioned and a lower positioned brand, resulting in lower brand evaluations for the higher positioned brand. For the lower-end brands, the above arguments imply that component sharing may increase their evaluation. Indeed, these lower-end brands may also start sharing higher-end brand associations (Janiszewski and Van Osselaer, 2000: Keller, 1998). Specifically, the use of a higher positioned brand component in a lower priced brand may signal a higher quality for that brand, increasing customer evaluation (Desai and Keller, 2002; Rao, Qu, and Ruekert, 1999).

\section{Impact of Brand Combination}

First, we expect that the effect of component sharing on changes in brand evaluation depends on the positioning of the higher-end and lower-end brands. We consider two combinations: (1) 
Luxury brand shares a component with a volume brand and (2) Volume brand shares a component with an economy brand (see Verhoef et al., 2007 for a similar distinction) ${ }^{5}$. Luxury brand - Volume Brand. Luxury brands are positioned in the premium end of the market. Economic theory suggests that consumers buy such brands in order to advertise their wealth, thereby achieving greater social status, also known as the Veblen effect (Bagwell and Bernheim, 1996). The branding literature suggests that these brands are purchased for exclusivity and communication of status (Kirmani, Sood, and Bridges, 1999; Park, Milberg, and Lawson, 1991). The brand's status is, amongst others, based on the customers' assumption that these brands are unique. If such brands now share components with a lower-positioned volume brand, their uniqueness would become tainted and the social status of owning them would severely diminish.

From the perspective of the volume brand components shared with a luxury brand may transfer quality and prestige to the volume brand (Simonin and Ruth, 1998). However, one might question whether this effect is so strong. Volume brands are already associated with having good quality components, and uniqueness associations (that can be derived from components shared with a luxury brand), are relatively less important for volume brands. Therefore, volume brands might not benefit that much from sharing components with luxury brands.

Volume brand-Economy brand. The negative effect of component sharing with an economy brand might be not so strong for volume brands, as brand uniqueness is not as important to a volume brand versus a luxury brand. In contrast economy brands sharing components with a volume brand may benefit substantially from sharing components with volume brands, because the relative good quality associations one has with volume brands, now also become associated

\footnotetext{
${ }^{5}$ Component sharing between luxury brands and economic brands is not considered in the first study, but is in our second study on the impact of component sharing on the market share of the involved brands
} 
with the economy brand. In sum, we expect that the luxury brand sharing with a volume brand is more affected by component sharing than a volume brand sharing components with an economy brand. In the same vein we expect that an economy brand benefits more from component sharing with a volume brand, than a volume brand sharing components with a luxury brand.

\section{Source of Component sharing}

In our study, we consider three sourcing formats: (1) the higher-end or higher positioned brand shares (sends) a component brand with (to) the lower-end or lower positioned brand (i.e. luxury brand to volume brand or volume brand to economy brand), (2) the higher-end brand and lower-end brand share the same component, (i.e. luxury brand with volume brand or volume brand with economy brand), and (3) the lower-end brand shares (sends) a component with (to) the higher-end brand (i.e. volume brand to luxury brand or economy brand to volume brand). Note, that the 'objective' end result is identical across the sourcing strategies: two sharing brands have the same component. Also note, that the framing is independent of the precise nature of the brand combination (see section 3.2). It can happen when a luxury brand (higher-end) shares components with a volume brand (lower-end or lower positioned) and when a volume brand shares components with an economy brand. Why then would the source of component sharing impact customer evaluation? Research on judgment and decision-making has shown that framing messages differently affects the evaluation of these messages (Levin and Geath, 1987; Shiv, Edell, and Payne, 1997; Thaler, 1985, Tversky and Kahneman, 1981). In our context, sourcing format 1 communicates that the higher-end brand sends its component to a lower positioned brand. Such message should mainly transfer positive consumer associations from the higher-end brand to the lower-end brand, but limit the (negative) transfer from the lower-end to the higher- 
end brand. Sourcing format 2 is more neutral and only communicates that the two brands have the same component without mentioning its original source. Sourcing format 3 is most negatively framed for the higher-end brand, as consumers may believe that lower-end brand components are inferior. As a result, format 3 should create severe negative effects on the higher-end brand's evaluation. Anecdotic evidence for this is how the luxury brand Jaguar is referred to as an upgraded Ford Mondeo, because it receives components from this Ford subbrand.

Thus, we expect that information about the source of the component (either a higher-end or a lower-end brand) will affect the evaluation of the brand receiving the component in a manner which is also in line with for example information integration theory (Anderson, 1971). However, we are also interested in whether component sharing will affect evaluations of the source brand. On one hand, one would not expect any impact of component sharing on the source brand, since information regarding component sharing does not communicate any objectively new information about the source brand (it is exactly the same component). On the other hand, based on least mean square connectionist models, one could argue that the evaluation of the source of the shared component can also change due to the component sharing (Janiszewski and Van Osselaer, 2000). According to these type of models, people can update the weight of attributes based on new information. Thus, new information about the component (i.e., other brands that use the same component), can lead to an update of the evaluation of this component, which transfers to an updated evaluation of the source brand. We expect such an update to occur only in source format 3 , where the component is sent from a lower-end brand to a higher-end brand. Only in this case, the (higher-end) receiver of the component calls for an 
update of the attribute weights, because a higher-end receiver signals that the component must be of good quality, which was not necessarily the case before.

Interestingly, it is unclear which sourcing format is better or worse for the lower-end brand. On the one hand, ingredient-branding literature would suggest that imputing a component from a higher-end brand with a higher quality reputation should have the most positive consequences for the lower-end brand (e.g. Park et al., 1996). On the other hand, identifying the lower-end brand as the source may communicate to consumers that the component quality of this brand is apparently so good, that a higher-end brand is using the same component.

Finally, the impact of component sharing on brand evaluation may depend on other conditions, such as the type of component and the initial brand evaluation (before component sharing). We investigate these conditions in an exploratory manner.

\section{Study 1: Brand Evaluation Consequences for Salient Component Sharing Strategies}

The main objective of the first study was to assess how making component sharing salient would affect brand evaluations. We do so by examining different brand combinations, sourcing strategies, and shared components. Appendix 1 details the pretest results, and the experimental procedures and measures, which we summarize below.

\section{Participants}

We collect our data by means of an Internet questionnaire to the panel of a Dutch market research agency. The selected respondents are 20-65 years old, and usually purchase new cars (not second-hand cars) in the full-size car market. This selection yields 179 respondents, of which 34 did not fully complete the questionnaire, leaving 145 respondents. The average age is 
43 years, approximately $75 \%$ is male, $88 \%$ earned an education of high school or higher, and $63 \%$ of respondents have an above average income. The relative high education and high income of our respondents is probably due to our focus on new large car buyers.

\section{Experimental Design}

Based on pre-tests we choose two sets of real brands: (1) Audi, Volkswagen and Skoda (A/V/S), and (2) Lexus, Toyota and Suzuki (L/T/S) as respectively the luxury, volume and economy brands. Our motivation for selecting these brand sets is threefold: (1) they are widely known in the respondent population, (2) they differ in terms of top-line contribution by luxury versus economy brands ${ }^{6}$, and (3) they cover Western brands, which are known for component sharing, and Japanese brands, which are reluctant to compromise 'product uniqueness' (Ykusawa, 1992; Fisher et al., 1999). As for component type (e.g. Eysenck and Keane, 1990; Desai et al. 2001) we select components that vary in terms of importance and visibility: engines, wipers, interior, brakes, design, wheels, chassis and shock absorbers.

First, respondents are assigned to one of the two brand sets (which resulted in 67 respondents for $\mathrm{A} / \mathrm{V} / \mathrm{S}$, and 78 respondents for $\mathrm{L} / \mathrm{T} / \mathrm{S}$ ). Following our theoretical discussion on brand combinations sourcing of components we used the following design for each brand set: a 2 (Brand Combination: Luxury-Volume [Lux Vol] versus Volume-Economy [VolEcon]) x 3 (Source Format: Higher-End [or higher positioned] to Lower-End [lower positioned: HiLow] versus Higher-End\&Lower-End [HI\&LOW] versus Lower-End to Higher-End [LowHI]) between-subjects factorial design. We combined this between-subjects design with a within-

\footnotetext{
${ }^{6}$ In 2009 sales, Dutch sales for Audi, VW and Skoda reached respectively 15,252; 38,182 and 7,768. The numbers for Lexus, Toyota and Suzuki are respectively 550; 37,487 and 13,398.
} 
subjects factor for the 8 shared component types. Each respondent is randomly assigned to one of the six conditions. The experimental manipulation is graphically clarified in Figure 1.

-- Insert Figure 1 about here --

The questionnaire started with some questions on car and brand ownership. Next, respondents saw pictures of the three brands in the brand set (see Appendix A), and were asked to evaluate the brand attractiveness on a 1-100 ( $1=$ absolutely unattractive, $100=$ absolutely very attractive) scale of each brand under study. In line with our brand classification significant differences in the brand evaluations between all considered brands in the brand set exist $(\mathrm{p}<0.01$; see Table 1 for average scores).

Next, we described to the respondent, that the manufacturer is planning to share components between two specific brands (i.e. Audi and Volkswagen). The description differed for the three source component conditions (see Table 2). One by one, we confronted the respondents with 8 components being shared. These components were randomly presented to the respondents to overcome any order effects. For each component, the respondent was asked to evaluate the attractiveness of the higher-end brand and the lower-end brand on a 1-100 scale. We ended the questionnaire with straightforward questions on income, education, age, and gender.

While our research design may create demand effects in general, our focus is on the differential impact of different component sharing conditions (see study 2 for an assessment of the impact of component sharing on the actual market shares of the involved brands). -- Insert Tables 1 and 2 about here --

Analysis 
The dependent variable is the change in customer evaluation of customer $i$ of the higher-end (he) and the lower-end brand (le) ${ }^{7}$ due to component sharing strategies (s), given by:

$$
\begin{aligned}
& \Delta \mathrm{EVA}_{\mathrm{i}, \mathrm{e} e, \mathrm{~s}}=\mathrm{EVA}_{\mathrm{i}, \mathrm{he}}-\mathrm{EVA}_{\mathrm{i}, \mathrm{he}, \mathrm{s}} \\
& \Delta \mathrm{EVA}_{\mathrm{i}, \mathrm{le}, \mathrm{s}}=\mathrm{EVA}_{\mathrm{i}, \mathrm{le}}-\mathrm{EVA}_{\mathrm{i}, \mathrm{le}, \mathrm{s}}
\end{aligned}
$$

As each respondent is confronted with 8 component types being shared, we have 8 observations per respondent. Hence, our data can be considered as panel data. To account for the interdependency between these 8 observations, we estimate a random effects model (Greene, 2002; Train, 2003), assuming the random effect $\left(u_{i}\right)$ for respondent $i$ is the same for each shared component. We include dummies for the experimentally manipulated conditions. For the brand combination, we include the dummy LUXVOL (Luxury-Volume), leaving the Volume Economy combination as the base case. For the component source, we include HILOW (Higher End to Lower End) and LOWHI (Lower End to Higher End), leaving HI\&LOW (no identified source) as the base scenario. A dummy BS is included to control for the brand set $(0=\mathrm{L} / \mathrm{T} / \mathrm{S}, 1=\mathrm{A} / \mathrm{V} / \mathrm{S})$. We include a vector of 7 dummies COMP for 7 of the shared components, using wipers as the benchmark (this component was considered least important in our pre-tests).

To control for the effect of the consumers' perceived brand evaluation of both the higherend, and lower-end brand, we also include the initial evaluation of these brands as determinants of changes in brand evaluation $\left(\mathrm{EVA}_{\mathrm{i}, \mathrm{he}}\right.$ and $\left.\mathrm{EVA}_{\mathrm{i}, \mathrm{le}}\right)$. Thereby, we expect that a higher initial evaluation of the higher-end brand will result in a more positive change in evaluation of the lower-end brand, while at the same time will result in a greater negative change in evaluation of

\footnotetext{
${ }^{7}$ We use this terminology to simplify our exposition. The evaluation of the higher-end brand in our experimental set up involves the evaluation of either luxury brand when sharing components with a volume brand or the evaluation of the volume brand when sharing components with the economy brand. In the same vein, the evaluation of the lowerend brand involves the evaluation of either the volume brand sharing components with the luxury brand or the evaluation of the economy brand when sharing components with the volume brand.
} 
the higher-end brand. For the initial evaluation of the lower-end brand, we expect that the positive change of the lower-end brand will be smaller if consumers already have a high initial evaluation of the lower-end brand. The negative change in evaluation of the higher-end brand will also be smaller if consumers already have a high initial evaluation of the lower-end brand.

Finally, we aim to control for observed consumer heterogeneity by a set of variables (denoted as X), including dummies for the ownership of the three considered brands in our brand sets (OWNLUX, OWNVOL, OWNECON), age, income, education and car expertise (how long the respondent has owned a car). The resulting random effects regression models are given by:

$$
\begin{aligned}
\Delta \mathrm{EVA}_{\mathrm{i}, \mathrm{he}}= & \beta_{0}+\beta_{1, \mathrm{he}} \mathrm{LUXVOL}_{\mathrm{i}}+\beta_{2, \mathrm{he}} \text { HILOW }_{\mathrm{i}}+\beta_{3 \mathrm{he}} \mathrm{LOWHI}_{\mathrm{i}}+\beta_{4, \mathrm{he}} \mathrm{BS}_{\mathrm{i}} \\
& +\gamma_{\text {,he }} \mathrm{COMP}_{\mathrm{ik}}+\delta_{1, \mathrm{he}} \mathrm{EVA}_{\mathrm{i}, \mathrm{he}}+\delta_{2, \mathrm{he}} \mathrm{EVA}_{\mathrm{i}, \mathrm{le}}+\lambda_{\mathrm{he}} \mathrm{X}_{\mathrm{i}}+\varepsilon_{\mathrm{ik}, \mathrm{he}}+\mathrm{u}_{\mathrm{i}, \mathrm{he}} \\
\Delta \mathrm{EVA}_{\mathrm{i}, \mathrm{le}}=\quad & \beta_{0}+\beta_{1, \mathrm{le}} \mathrm{LUXVOL}_{\mathrm{i}}+\beta_{2, \mathrm{le}} \mathrm{HILOW}_{\mathrm{i}}+\beta_{3, \mathrm{le}} \mathrm{LOWHI}_{\mathrm{i}}+\beta_{4, \mathrm{le}} \mathrm{BS}_{\mathrm{i}} \\
& +\gamma_{\text {le }} \mathrm{COMP}_{\mathrm{ik}}+\delta_{1, \mathrm{le}} \mathrm{EVA}_{\mathrm{i}, \mathrm{le}}+\delta_{2, \mathrm{le}} \mathrm{EVA}_{\mathrm{i}, \mathrm{le}}+\lambda_{\mathrm{le}} \mathrm{X}_{\mathrm{i}}+\varepsilon_{\mathrm{ik}, \mathrm{le}}+\mathrm{u}_{\mathrm{i}, \mathrm{he}}
\end{aligned}
$$

with $\varepsilon_{\mathrm{ik}}$ the unique random term for respondent $\mathrm{i}$, and component $\mathrm{k}$, and $\mathrm{u}_{\mathrm{i}}$ is the respondentspecific term. Both $\varepsilon_{\mathrm{ik}}$ and $\mathrm{u}_{\mathrm{i}}$ are bivariate normal distributed with means $(0,0)$, variances $\sigma^{2}$ and $\varpi^{2}$, correlation 0 , and also assumed uncorrelated across individuals. The models are estimated in LIMDEP 8.0 (Greene, 2002).

\section{Descriptive Results}

Before presenting our estimation results, we briefly discuss the descriptive findings in Table 3. For the total sample, we find that component sharing on average decreases the evaluation for the higher-end brand by 6.23 (standard deviation $=15.26$ ), while it increases evaluation for the lower-end brand by 2.61 (s.d. =14.87). Both values significantly differ from $0(\mathrm{p}<0.01)$, and are in line with our expectations for both sets of brands. Interestingly, the absolute change for the 
higher-end brand is significantly larger than the absolute change for the lower-end brand $(\mathrm{p}<0.01)$. We also find significant differences between the two brand-sets: the average deviation is significantly larger for $\mathrm{L} / \mathrm{T} / \mathrm{S}$, than for $\mathrm{A} / \mathrm{V} / \mathrm{S}$. As noted before, a possible rationale is that component sharing is more widely known among $\mathrm{A} / \mathrm{V} / \mathrm{S}$ brands than among $\mathrm{L} / \mathrm{T} / \mathrm{S}$ brands (in fact, Suzuki is a separate brand not owned by the Toyota group). Hence, information on component sharing may be more surprising news to consumers for $\mathrm{L} / \mathrm{T} / \mathrm{S}$, while they may have incorporated possible component sharing for $\mathrm{A} / \mathrm{V} / \mathrm{S}$ in their initial brand evaluations.

-- Insert Tables 3 and 4 about here --

\section{Change in Evaluation for the Higher End brand}

Estimation results of equations (4) are displayed in the first two columns of Table 4. For interpretation of the coefficients, it is important to note that a negative coefficient implies a larger negative change in evaluation of the higher-end brand.

Effect of Brand Combination. We find that the change in evaluation of the higher-end brand depends on the type of brand combination, as we find a negative significant effect of LUXVOL $(\mathrm{p}<0.01)$. Thus, if a luxury brand shares components with a volume brand, the negative change in evaluation is larger than when the volume brand shares components with an economy brand. Note also, that we find a significant negative effect of the initial evaluation of the higher-end brand $\left(\mathrm{EVA}_{\mathrm{he}}\right)(\mathrm{p}<0.01)$. The opposite occurs for the initial evaluation of the lower-end brand $\left(\mathrm{EVA}_{\mathrm{le}}\right)$ : component sharing with a better-evaluated lower-end brand is less harmful for the higher-end brand $(\mathrm{p}<0.01)$. 
Effect of Source and Type of Component. The identified source of component sharing does significantly affect the changes in evaluation of the higher-end brand. We find that the largest negative change occurs when the lower-end brand is named as the component source (LOWHI) $(\mathrm{p}<0.01)$. The smallest change occurs when naming the higher-end brand as the source (HILOW) $(\mathrm{p}<0.01)$. Our results also show that the negative change in evaluation is significantly larger for $\mathrm{L} / \mathrm{T} / \mathrm{S}$ than for $\mathrm{A} / \mathrm{V} / \mathrm{S}(\mathrm{p}<0.01)$.

With respect to the components, we find that sharing the interior $(\mathrm{p}<0.01)$, wheels $(\mathrm{p}<0.05)$ and the chassis $(\mathrm{p}<0.05)$ have a significant larger negative impact than sharing the wiper component.

\section{Change in Evaluation for the Lower-End Brand}

For interpretation of the coefficients in the last column of Table 4, note that a positive coefficient implies a larger positive change in evaluation of the lower-end brand. Our findings for brand combination mirror those for the evaluation change in the higher-end brand.

Effect of Brand Combination. The change in evaluation of the volume brand when sharing components with the luxury brand is smaller than the change in evaluation of the volume brand sharing with the economy brand $(\mathrm{p}<0.01)$. The initial evaluation of the two brands (higher-end and lower-end) also affects the change in evaluation of the lower-end brand. The change is larger when the higher-end brand has a high initial evaluation $\left(\mathrm{EVAL}_{\mathrm{he}}\right)(\mathrm{p}<0.01)$, while it is lower when the lower-end brand has a high initial evaluation $\left(\mathrm{EVAL}_{\mathrm{le}}\right)(\mathrm{p}<0.01)$. 
Effect of Source and Type of Component. Our results also show that the change in evaluation of the lower-end brand depends on the source of the component. We find that the largest change occurs when the lower-end brand functions as a source (LOWHI) of the shared components ( $\mathrm{p}$ $<0.01)$. Interestingly, the smallest evaluation increase of the lower-end brand occurs when the higher-end brand is named as a source (HILOW) $(\mathrm{p}<0.01)$. This finding is surprising, as the ingredient branding literature would suggest that specifying the higher-end brand as the source should yield the largest evaluation increase for the lower-end brand.

We do not find strong differences between the studied components, The car engine is the sole component that has significantly larger positive effect on the receiving brand $(\mathrm{p}<0.05)$.

\section{Summary-Discussion}

In this experiment we explicitly communicated the component sharing strategy to consumers. Overall, we find that component sharing harms customer evaluation of the higher-end brand, while it benefits the lower-end brand. The size of this negative effect, however, depends on the brand combination, and the type of brand identified as the source of the component. The economy brand appears to benefit most from component sharing with a volume brand. Importantly, identifying the lower-end brand as the source of the shared component helps evaluations of this lower-end brand. This appears counterintuitive, as one would expect that a component from the higher-end brand might function as a kind of ingredient for the lower-end brand. One explanation for this finding is that consumers will update their evaluation of the component based on the status of the receiver of the component, and subsequently also update their evaluation of the source of the component ${ }^{8}$.

\footnotetext{
${ }^{8}$ In the experiment we also recorded willingness to pay and verified it had a strong positive relation with brand evaluation. We refer to an earlier working paper (authors 2007) for a more detailed discussion of this analysis.
} 


\section{Study 2: Market Share Consequences of Component Sharing}

The results of study 1 may be driven by the presented salience of component sharing. Indeed, in a follow-up experiment where we made other purchase characteristics more salient than component sharing, we do not find significant evaluation effects of component sharing (results available upon request). Thus, the empirical question remains to what extent consumers actually use information on component sharing while buying cars. Based on our results, we may expect negative market share consequences for a higher-end brand sharing components. For the lowerend brand the opposite might occur (Keller and Lehmann, 2006). To assess these consequences we collected sales data and data on specific component sharing practices of a specific set of brands, which are known to share components: Audi (luxury), Volkswagen (volume), Seat (economy) and Skoda (economy). Among these brands, sharing occurred both from higher-end to lower-end brands, and vice versa. The degree of component sharing differs for different types of cars, but has been documented to range from 20\% (between the Audi TT and the Audi A3) up to $90 \%$ similar components (between the VW Lupo and the Seat Arosa) in the time period that is covered by our data (Wells 2001). On average, about 50\% of the components is shared with other models (from both the same and different brands) within the same platform. We observe brand level sales-data, average price and new product introductions of the four brands for the period between 1994 and 2001. We collected data on component sharing activities based on platform information (http://en.wikipedia.org/wiki/List_of_Volkswagen_Group_platforms). For the time period of our sales-data, we collected data considering which brand was the first on a platform, and when other brands joined that same platform. If another brand joined a platform, we treated this as a case in which both the first brand on the platform sends a component to the 
newcomer, and the newcomer received a component from the first brand on the platform (see Appendix B for details).

\section{Model specification}

Our dependent variable is market share of a brand $\mathrm{X}$ at time $\mathrm{t}$. As explanatory variables, we include lagged market share, price changes, model changes and component (COMP) sharing events involving the brand, and monthly seasonal dummies (SD), as displayed in equation 5:

$$
\begin{aligned}
& \text { SHAREt }=\alpha+\rho * \text { SHAREt }-1+\lambda{ }^{*} \Delta \text { PRICEt }+\sum_{i=1}^{I} \gamma i^{*} \Delta M O D E L i+ \\
& \sum_{j=1}^{J} \beta j^{*} \Delta C O M P j++\sum_{k=2}^{12} \varphi k^{*} S D k+\varepsilon t
\end{aligned}
$$

Both model changes and component sharing events are coded as step dummies, i.e. 0 before the event and 1 thereafter. For luxury brand Audi, our data period includes 2 model changes (new Audi A4 and a new Audi A8 model) and 3 component sharing events, involving Audi sharing its platform with respectively VW, Seat and Skoda. For volume brand Volkswagen, the data period includes 1 model change (introduction of Golf Mk4) and 2 component sharing events, involving respectively economy brands SEAT and Skoda sharing its platform with VW. For economy brand Seat, the data period includes 1 model change (the second generation of the SEAT Toledo) and 2 component sharing events: receiving the platform from luxury brand Audi and sharing its platform with volume brand VW. Likewise, economy brand Skoda saw 1 major model change (the Skoda Fabia) and 2 component sharing events: receiving the platform from luxury brand Audi and sharing its platform with volume brand VW. Unit root tests showed that prices were evolving for each brand, while market share was evolving for both economy brands. We proceed by taking the first difference of the evolving variables. 
For each brand, we estimate the model with and without the component sharing events. In each case, we find that including the component sharing events improves model fit in terms of adjusted $\mathrm{R}^{2}$ and Information Criteria. Thus, we conclude that accounting for component sharing ads to our power to explain market share.

\section{Model Results}

Table 5 shows the model estimation results for each brand (for space constraints, we do not report the constant and seasonality coefficient estimates), with significant coefficient estimates in bold. In each case, the model explains the majority of the variation in the dependent variable (market share for luxury and volume brands, market share changes for both economy brands).

<Insert Table 5 about here>

For luxury brand Audi, we obtain the expected signs for all significant coefficient estimates. While the component sharing with volume brand Volkswagen and with economy brand Skoda did not significantly affect Audi's market share, the component sharing with economy brand Seat decreased Audi's market share with 0.27 points. In the case of volume brand Volkswagen, receiving components from economy brand Skoda yielded a market share decrease significant at the $10 \%$ level. On the positive side, market share changes of economy brands SEAT and Skoda got a boost when luxury brand Audi shared its platform with these brands. Moreover, economy brand Skoda got a boost when it shared its platform with volume brand Volkswagen confirming our experimental results.

In sum, our econometric analysis suggests that component sharing may affect market shares of the involved brands. As expected from our experimental results, higher-end brands sharing with lower positioned brands may lose market share, while lower-end brands may gain 
market share when they share with higher positioned brands. Moreover, the smaller economy brands Seat and Skoda benefit, but not the volume brand Volkswagen, as the latter already has a quality reputation. We acknowledge that many possible explanations exist for why certain component sharing events did significantly affect market shares of the involved brands, while others did not. They include the type of component shared and the extent to which component sharing was publicized by the brands or their competitors, and thus made salient in the consumers' minds. We could not obtain reliable data on these variables. Moreover, the relative market shares of the involved brands and the timing of component sharing may matter. Future research may measure these variables in the marketplace to support or reject these explanations.

\section{Conclusions and Avenues for Future Research}

\section{Theoretical Discussion}

This paper analyzed the evaluation and market share consequences of component sharing by executing one experimental study and analyzing market share data. Our study contributes to the extensive literature on branding (e.g., Keller and Lehmann, 2006), as it is the first to empirically investigate the effect of component sharing on brands in the vertical product line. Our results show some differences in evaluation effects between shared components. However, these differences are not substantial. This might imply that the issue that brands share components is more important, than what is actually being shared. Brand evaluations are most affected by the brand combination and the sourcing of component sharing.

Effects of Brand Combination. The results of our experiment show that sharing components between brands in the vertical product line has negative consequences for the higher positioned 
brand, while it has positive consequences for the lower positioned brand. Furthermore, our results suggest that it is important to differentiate between different types of higher-end brands. Given the higher prestige of a luxury brand, the negative effects of sharing with a lower-end brand are stronger for the luxury brand than for a volume brand. However, although volume brands are less affected by sharing with economy brands, these brands also benefit less from sharing components with a luxury brand than economy brands benefit from sharing with a volume brand. Overall, we find that (consumer evaluations for) volume brands are less susceptible to component sharing activities.

Effects of Source. Importantly, the source of sharing influences the size of the negative effect. Higher-end brands are less affected, when they send a component to a lower-end brand. Remarkably, lower-end brands benefit most, when they send a component to a higher-end brand. One might expect the opposite. One explanation is that sending a component to a higher-end brand signals that the quality of the component is higher than expected, leading to an update of component evaluations, and also to an updated evaluation of the lower-end brand sending (and possessing) this component. This explanation is in line with predictions one could derive from least mean square connectionist models (Janiszewski and Van Osselaer, 2000). Furthermore, in line with our results, this model would not predict updates of the evaluation of the higher-end brand when it is the source of a component which is shared with a lower-end brand. In this case, the information about the receiving brand does not add to the predictive value of the component as a quality cue of the higher-end brand sending the component. 
Exploratory Market Share Analysis. One important limitation of the experiment is that component sharing is communicated very explicitly to consumers. One could argue that this might result in stronger effects and that it is questionable, whether these results would be found in the market as well. Moreover, we only studied evaluation not behavioral effects. We therefore examined the impact of component sharing on market share of four brands, which are known to share components. Our results provide some interesting results. First, our analysis shows relatively strong evidence that economy brands tend to benefit from sharing with higher-end brands. Second, our analysis tends to suggest that especially luxurious brands face a risk of losing market share, when they share components with an economy brand ${ }^{9}$. Third, the studied volume brands do not benefit from sharing a component with a luxurious brand, while we also do not find strong evidence that sharing components with an economy brand negatively affects this brands market share. These findings confirm the results of our first experiment that the luxury brand should be careful with sharing components. Luxury brands lose their uniqueness and status, which is so important for their position in the market. It also confirms the results of our experiment, that the volume brand is probably less affected. Finally, it confirms that economy brands may benefit strongly from sharing components with higher-positioned brands.

\section{Management Implications}

Although sharing components may look good in the board room due to cost-savings and longer use and thus revenues of developed components, manufacturers should incorporate likely consumer reaction in their component sharing decision. Our results suggest three relevant implications for manufacturers sharing components between brands. First, they should be very

\footnotetext{
${ }^{9}$ We note that our findings in this respect require further attention, as we only found this effect for the Audi-Seat combination and not for the Audi-Skoda combination.
} 
reluctant to share components between luxury and lower positioned brands, as it tends to hurt both the evaluation and the market share of luxury brands. Second, our results suggest that sharing components between a volume brand and an economy brand may be a viable strategy. Our evidence suggests less severe effects for the evaluation of the volume brand and only limited (or no) negative market share effects for this brand, whereas the economy brand benefits from sharing these components. Third, our results suggest that the negative effects for the higher-end brand and the positive effects for the lower-end brand are mitigated by the source of the component. This implies that firms should carefully look at how they communicate or frame their component sharing.

\section{Research Limitations and Future Research}

The current study has several limitations, including the choice of country and respondent sample, the study of only one industry and the focus on only six brands. Moreover, we focused on the customer side of component sharing; which received little previous study. Other parts of the profitability equation are needed to balance the revenue and cost drivers. For instance, we could not obtain precise information on the component cost-coefficient (Desai et al., 2001) for a representative group of manufacturers (such information is highly confidential and likely differs

per firm). Future research can also use a between-subjects design to assess the differences between components, and study boundary conditions, such as timing of sharing (i.e., immediately or after 1 year).

One particular limitation with regard to the design of the experimental study is that this study might have created demand-effects. As a consequence, this study might overstate the general effect of component sharing on brand evaluations. The econometric analysis of market shares 
does not suffer from this limitation, but its high external validity came at the cost of our inability to control and measure potentially important factors, including communication by the brands and their competitors. However, together the two studies do indicate that component sharing can affect consumers' evaluations of the brands involved. Still, a very valuable follow-up study would be to build up a large database in which for multiple brands component sharing practices are collected and beyond that also multiple other marketing actions (i.e. advertising, new product introductions, promotions) are included (e.g., Pauwels et al., 2004) over a long time period. Having such a database allows one to assess potential short- and long-term consequences of component sharing across brands and would probably enable a study on how firms can mitigate potential negative effects (i.e. through increased advertising).

In this study we also suggested a number of theoretical motivations (i.e., change in quality perceptions, loss of uniqueness, lack of differentiation), why component sharing affects brand performance. Our research does not formally test these reasons, as we only show consequences for brand evaluations and market share. Future research could focus more on the underlying theoretical variables, and specifically investigate whether component sharing affects these underlying variables, which subsequently affect brand evaluations. Experimental research showing the possible mediating role of these variable, would be an excellent opportunity for future research on component sharing.

Despite these limitations, the current study provides several key and interesting insights which are relevant to the decision on and the execution of component sharing. As consumers are knowledgeable about component sharing practices, managers should aim for solutions that look good in the boardroom and in the showroom. 


\section{References}

Anderson, N. H. (1971). Integration Theory and Attitude Change. Psychological Review 78(3):

171-206.

Bagwell, L.S. and Bernheim, B.D. (1996). Veblen Effects in a Theory of Conspicuous Consumption. The American Economic Review 86(3):349-373.

Bloch, P.H. (1995). Seeking the Ideal Form: Product Design and Consumer Response. Journal of Marketing 59(3):16-29.

Bolton, L.E., Warlop, L., and Alba, J.W. (2003). Consumer Perceptions of Price (Un)Fairness. Journal of Consumer Research 29(4):474-490.

Desai, K.K. and Keller, K.L. (2002). The Effect of Ingredient Branding Strategies on Host Brand Extendibility. Journal of Marketing 66(1):73-93.

Desai, P., Kekre, S., Radhakrishnan, S., and Srinivasan, K. (2001). Product Differentiation and Commonality in Design: Balancing Revenue and Cost Drivers. Management Science 47(1):37-51.

De Tijd (2004). The Same or Still Different? (Hetzelfde of toch anders?). February 4, 17

Echambi, R., Arroniz, I., Reinartz, W., and Lee, J. (2006). Empirical Generalizations from Brand Extension Research: How Sure Are We? International Journal of Research in Marketing 23(3):253-261.

Eysenck, M.W. and Keane, M.T. (1990). Cognitive Psychology: A Student's Handbook, London: LA.

Financial Times (2004).Cars Worth More Than the Sum of Their Shared Parts. January 2(9):16. 
Fisher, M., Ramdas, K., and Ulrich, K. (1999). Component Sharing in the Management of Product Variety: A Study of Automotive Braking Systems. Management Science 45(3):297315.

Greene, W.H. (2002). Limdep version 8.0 econometric modeling guide vol. 2. Econometric Software Inc, Plainview NY: Econometric Software.

Janiszewski, C. and Van Osselaer, S.M.J. (2000). A Connectionist Model of Brand-Quality Associations. Journal of Marketing Research 37(3):331-350.

Keller, K.L. (1998). Strategic Brand Management, Upper Saddle River: Prentice Hall.

Keller, K.L. and Aaker, D.A.(1992). The Effects of Sequential Introduction of Brand Extensions. Journal of Marketing Research 29(1):35-50.

Keller, K.L. and Lehmann, D.R. (2006). Brands and Branding: Research Findings and Future Priorities, Marketing Science 25(6):740-759.

Kerwin, K. (2004). Ford Learns the Lessons of Luxury. Business Week March 1:72-73.

Kirmani, A., Sood, S., and Bridges, S. (1999). The Ownership Effect in Consumer Response to Brand Line Stretches. Journal of Marketing 63(1):88-101.

Krishnan, V. and Gupta, S. (2001). Appropriateness and Impact of Platform-Based Product Development. Management Science 47(1):52-68.

Levin, I.P. and Gaeth, G.J. (1987). How Consumers are Affected by the Framing of Attribute Information Before and After Consuming the Product. Journal of Consumer Research 15(3):374-378.

Loken, B. and John, B.R.. (1993). Diluting Brand Beliefs: When do Brand Extensions have Negative Impact? Journal of Marketing 57(3):71-84. 
Moore, W.L., Louviere, J.J., and Verma, R. (1999). Using Conjoint Analysis to Help Design Product Platforms. Journal of Product Innovation Management 16(1):27-39.

Nagle, T.T. and Holden, R.K. (1995). The Strategy and Tactics of Pricing. $2^{\text {nd }}$ Edition. Englewood Cliffs, NJ: Prentice Hall.

Park, C.W., Milberg, S., and Lawson, R. (1991). Evaluation of Brand Extensions: The Role of Product Level Similarity and Brand Concept Consistency. Journal of Consumer Research 18(2):185-193.

Park, C.W., Jun, S.Y., and Shocker, A.D. (1996). Composite Branding Alliances: An Investigation of Extension and Feedback Effects. Journal of Marketing Research 33(4):453466.

Pauwels, K., Silva-Risso, J., Srinivasan, S., and Hanssens, D.M. (2004). New Products, Sales Promotions and Firm Value, with Application to the Automobile Industry. Journal of Marketing 68(4):142-156.

Ramdas, K. and Sawhney, M.S. (2001). A Cross-Functional Approach to Evaluating Multiple Line Extensions for Assembled Products. Management Science 47(1):22-26.

Randall, T., Ulrich, K. and Reibstein, D. (1998). Brand Equity and Vertical Product Line Extent. Marketing Science 17(4):356-379.

Rao, A.R., Qu, L. and Ruekert, R.W. (1999). Signaling Unobservable Product Quality through a Brand Ally. Journal of Marketing Research 36(2):258-268.

Sherman, R. and Hoffer, G. (1971). Does Automobile Style Change Pay Off? Applied Economics 3(3):153-165.

Shiv, B., Edell, J.A., and Payne, J.W.. (1997). Factors Affecting the Impact of Negatively and Positively Framed Messages. Journal of Consumer Research 24(3):285-294. 
Simonin, B.L. and Ruth, J.A. (1998). Is a Company known by the Company it Keeps? Assessing the Spillover Effects of Brand Alliances on Consumer Brand Attitudes. Journal of Marketing Research 35(1):30-42.

Thaler, R. (1985). Mental Accounting and Consumer Choice. Marketing Science 4(2):199-214.

Train, K.E. (2003)._Discrete Choice Methods with Simulation. Cambridge, Cambridge University Press.

Tversky, A. and Kahneman,D. (1981). The Framing of Decisions and the Psychology of Choice. Science 211(4481):453-458.

Venkatesh R. and Mahajan, V. (1997). Products with Branded Components: An Approach for Premium Pricing and Partner Selection. Marketing Science 16(2):146-165.

Verhoef, P.C., Langerak, F., and Donkers, B. (2007). Understanding Brand and Dealer Retention in the New Car Market: The Moderating Role of Brand Tier. Journal of Retailing 83(1):97113.

Völckner F. and Sattler, H. (2006). Drivers of Brand Extension Success, Journal of Marketing 70(2):18-34.

Völckner F. and Sattler, H. (2007). Empirical Generalizations about Brand Extensions, International Journal of Research in Marketing 24(2):149-162.

Wells, P. (2001). Platforms: Engineering panacea, marketing disaster? Journal of Materials Processing Technology, 115, 166-170.

White, J.B. (2001). Ford and GM Work to Restore Prestige of Lincoln and Cadillac. The Wall Street Journal, December 3

White, J.B. (2004). Auto Industry's Rush to Hammer out Alliances Produces Mixed Results. The Wall Street Journal, April 26. 
Ykusawa, S. (1992).Toyota Motor Corporation, Interview by M. Fisher and J.P. Mac Duffie. 


\section{Appendix: Pretest, and experimental procedures and measures}

\section{A1. Pretests}

For a European (Audi, Volkswagen and Skoda) and a Japanese brand combination (Lexus, Toyota and Suzuki), we choose cars of the same size: Audi A4 Sedan, Volkswagen Passat Sedan and the Skoda SuperB Sedan; and Lexus IS 2000, Toyota Corolla Verso, and Suzuki Lilian. The dealer prices of the considered brands for Audi, VW and Skoda are respectively 33.000 Euro, 29.500 Euro, and 26.000 Euro. For Lexus, Toyota and Suzuki these prices are respectively 34.000 Euro, 26.000 Euro, and 17.000 Euro. In order to enhance external validity, we also provided typical information (identical across cars) on motor, gear and steering specifications. Some validity for our classification is provided in a separate pre-study, where we asked 50 consumers to evaluate the brands in terms of perceived price level, perceived prestige level and perceived quality on a 10-point scale. The average scores for Audi are 7.48, 8.01 and 7.92. For Volkswagen, these average scores are 7.01, 7.77 and 7.48. The average scores for Skoda are 5.28, 4.77 and 6.05. Pair wise t-tests reveal significant differences $(\mathrm{p}<0.05)$ between Audi and Volkswagen, Audi and Skoda, and Volkswagen and Skoda on all these variables. We also asked these respondents to classify the brands in the luxury segment, the volume segment and the economy segment. In line with our classification $84 \%$ considered Audi as a luxury brand, $60 \%$ considered Volkswagen as a volume brand and $74 \%$ considered Skoda as an economy brand. Thus, these brands can indeed be considered as luxury, volume and economy brands. These 50 consumers also evaluated Toyota and Suzuki. The average scores on perceived price level, perceived prestige level and perceived quality on a 10-point scale for Lexus are 7.35, 7.48, and 7.40, for Toyota are 6.91, 7.14 and 7.78 and for Suzuki are 5.46, 5.67, and 6.36. These results show that based on price, and prestige level Lexus can be considered as prestige brand, Toyota as 
volume brand, while Suzuki can be considered as an economy brand. Note the very high quality score for Toyota, which reflects its reputation as the most reliable brand in the Dutch market. $76.9 \%$ of respondents classified Lexus as a prestige brand, $72 \%$ classified Toyota as volume brand, while $75 \%$ classified Suzuki as economy brand. Overall, these results support our classification of the considered brands.

We also aim to select components that vary in terms of importance and visibility, drawing upon various sources: statements in prior literature on component sharing practices in this industry (Fisher et al., 1999) and desk research by a research assistant. The selected 8 components are engine, brakes, wipers, platform/chassis, design, interior, shock absorbers, and wheels, as shown in table 1.114 Dutch consumers master students evaluated the importance $(1=$ not important, $7=$ very important $)$ and the visibility of the components $(1=$ not visible, $7=$ very visible). We found substantial variation in the importance and visibility of these components 


\section{Appendix A}

\section{Experiment material: picture and information on the three brands}

\section{A: Audi/Volkswagen/Skoda}

Audi A4: Important characteristics of this car are:

2.0 I motor, $100 \mathrm{KW}$

5 gears

Power steering

Air conditioning

Price: 33.000 Euro

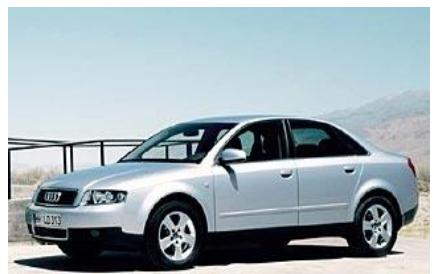

Volkswagen Passat: Important characteristics of this car are:

2.0 I motor, $100 \mathrm{KW}$

5 gears

Power steering

Air conditioning

Price: 29.500 Euro

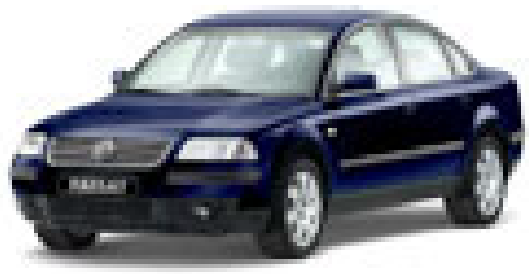

Skoda SuperB: Important characteristics of this car are:

2.0 I motor, $100 \mathrm{KW}$

5 gears

Power steering

Air conditioning

Price: 26.000 Euro

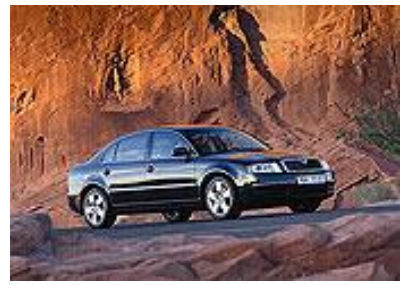




\section{B: Lexus/Toyota/Suzuki}

Lexus IS 2000 Sport Business: Important characteristics of this car are:

$2.0 \mathrm{I}$ motor, $100 \mathrm{KW}$

5 gears

Power steering

Air conditioning

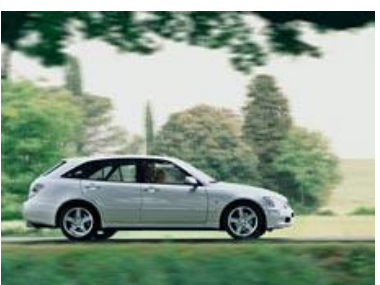

Price: 34.000 Euro

Toyota Corolla Verso: Important characteristics of this car are:

1.6 I. Motor, $75 \mathrm{KW}$

5 gears

Power steering

Air conditioning

Pice: 26.000 Euro

Suzuki Lilian: Important characteristics of this car are:

1.6 I. Motor, $75 \mathrm{KW}$

5 gears

Power steering

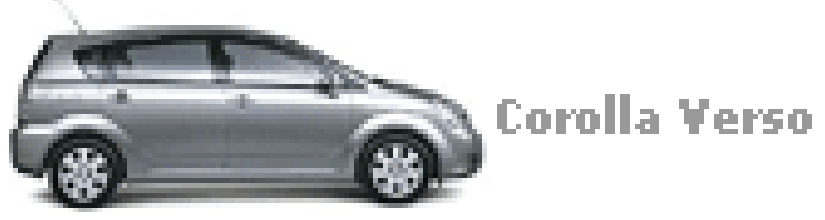

Air conditioning

Priice: 17.000 Euro 
Appendix B

Volkswagen Group Model Changes and Platforms

We analyze monthly Dutch data on market share, price, model changes and component sharing for the 3 Volkswagen brands: luxury brand Audi (with average price of 50,619 guilders and market share of $1.91 \%$ ), volume brand Volkswagen (average price 32,629 guilders and market share of $11.02 \%$ ), economy brand Seat (with average price of 24,095 guilders and market share of $2.65 \%$ ) and Skoda (with average price of 21,611 guilders and market share of $0.53 \%$ ). Our data period runs from January 1994 till October 2001, for a total of 94 monthly observations.

\section{Model Changes}

During the period of analysis, Audi experienced 2 major model changes. The A04 platform introduced in January 1995 represented "all-new platform with a longer wheelbase and wider track" (CarsGuide.com 2009) than the predecessor for Audi A4 A4. The new engine and exterior design in January 2000 for the Audi A8 "made it a strong competitor among more established brands" (Car Connection 2000). The volume brand Volkswagen has one major model changes in our data period: 1998 saw the upmarket introduction of the Golf Mk4. Economy brand Seat experienced one major model change: the second generation of its Seat Toledo in 1998 "was more rounded than the previously boxy shape and had a much more fluid design" over its 19911997 predecessor (Wikipedia 2009). Finally, as the least expensive car with the lowest market share, Skoda had only one major model change on its own in our data: the 1999 Skoda Fabioa (A04 platform).

\section{Platforms shared}

During the period of analysis, we identified 3 platforms that were shared by at least two of the analyzed brands, and that started with one brand. They are displayed in below table.

\begin{tabular}{ll}
\hline Platform & Brands \\
\hline A03 & Starts with Seat 1993 \& 1994 \\
& Volkswagen Polo Playa joins in 1996 \\
A04 & Starts with Skoda Fabia in 1999 \\
& Volkswagen Polo MK4 joins in 2001 \\
& Starts with Audi A3 in 1996 \\
A4 & Volkswagen Golf joins in 1997 \\
& Seat Leon joins in 1999 \\
& Skoda Octavia joins in 1998 \\
\hline
\end{tabular}

\section{References}

Car Connection (2000), “2000 Audi A8 review”, accessed August 222009 at: http://www.thecarconnection.com/fullreview/audi_a8_2000 CarsGuide.com (2009),"Audi A4- 1995-2002 model watch", accessed August 222009 at: http://www.carsguide.com.au/site/news-and-reviews/story/audi_a4_1995_2002_model_watch Wikipedia (2009), "SEAT Toledo", http://en.wikipedia.org/wiki/SEAT_Toledo 


\section{Figure 1}

Graphical representation of experimental conditions of between-subjects design of brands, brand combination and sourcing.

\begin{tabular}{|c|c|c|c|c|c|}
\hline & \multicolumn{4}{|c|}{ Brands } \\
\hline & & \multirow{2}{*}{\multicolumn{2}{|c|}{$\begin{array}{c}\text { Audi, Volkswagen and Skoda } \\
\text { Brand Combination }\end{array}$}} & \multirow{2}{*}{\multicolumn{2}{|c|}{$\begin{array}{c}\text { Lexus, Toyota and Suzuki } \\
\text { Brand Combination } \\
\end{array}$}} \\
\hline & & & & & \\
\hline & & Luxury-Volume & $\begin{array}{l}\text { Volume - } \\
\text { Economy }\end{array}$ & $\begin{array}{l}\text { Luxury- } \\
\text { Volume }\end{array}$ & $\begin{array}{l}\text { Volume - } \\
\text { Economy }\end{array}$ \\
\hline \multirow{3}{*}{$\begin{array}{l}\text { Sourcing of } \\
\text { Component } \\
\text { Sharing }\end{array}$} & $\begin{array}{l}\text { Higher-end to } \\
\text { Lower-end }\end{array}$ & $\begin{array}{c}\text { Audi to } \\
\text { Volkswagen }\end{array}$ & $\begin{array}{c}\text { Volkswagen } \\
\text { to Skoda }\end{array}$ & $\begin{array}{l}\text { Lexus to } \\
\text { Toyota }\end{array}$ & $\begin{array}{l}\text { Toyota to } \\
\text { Suzuki }\end{array}$ \\
\hline & $\begin{array}{l}\text { Higher-end } \\
\text { \& Lower-end }\end{array}$ & $\begin{array}{c}\text { Audi \& } \\
\text { Volkswagen }\end{array}$ & $\begin{array}{l}\text { Volkswagen } \\
\text { \& Skoda }\end{array}$ & $\begin{array}{c}\text { Lexus \& } \\
\text { Toyota }\end{array}$ & $\begin{array}{l}\text { Toyota \& } \\
\text { Suzuki }\end{array}$ \\
\hline & $\begin{array}{l}\text { Lower-end to } \\
\text { Higher-End }\end{array}$ & $\begin{array}{l}\text { Volkswagen to } \\
\text { Audi }\end{array}$ & $\begin{array}{c}\text { Skoda to } \\
\text { Volkswagen }\end{array}$ & $\begin{array}{l}\text { Toyota to } \\
\text { Lexus }\end{array}$ & $\begin{array}{l}\text { Suzuki to } \\
\text { Toyota }\end{array}$ \\
\hline
\end{tabular}

Table 1:

Initial Average Evaluations (standard deviations) for Brands

\begin{tabular}{lcc}
\hline & Evaluation & Price (in Euros) \\
\hline Audi & $73.3(13.1)$ & $26,776(9,353)$ \\
VW & $68.4(13.4)$ & $24,356(6,718)$ \\
Skoda & $61.6(16.7)$ & $19,582(7,953)$ \\
Lexus & $66.1(20.1)$ & $25,609(7,975)$ \\
Toyota & $59.74(18.0)$ & $20,343(4,392)$ \\
Suzuki & $54.9(17.3)$ & $15,186(6,230)$ \\
\hline
\end{tabular}

Table 2:

Source Component Scenarios

General Introduction In the car-industry it may occur, that car manufacturers use the same components in different brands. This occurs mainly when manufacturers offer multiple brands. For instance, Brand A may have the same brakes as Brand B.

\footnotetext{
Higher-end to lower-end The manufacturer has decided to use component (name) in the lower-end (name) brand that is also used in the high-end (name) brand

Higher-end \& Lower-end The manufacturer has decided that the component (name) in both the highend (name) and lower-end brand is equal.

Lower-end to Higher-end The manufacturer has decided to use component (name) in the higher-end (name) brand that is also used in the lower-end (name) brand.
} 
Table 3:

Descriptive Statistics on Experimental Conditions ( $N=1160)$

\begin{tabular}{|c|c|c|c|c|c|}
\hline $\begin{array}{l}\text { Brand Positioning } \\
\text { Combination }\end{array}$ & $\begin{array}{l}\text { Higher- } \\
\text { End } \\
\text { Brand }\end{array}$ & $\begin{array}{l}\text { Lower } \\
\text { End- } \\
\text { Brand }\end{array}$ & $\begin{array}{l}\text { Source Format (Framing) of } \\
\text { Component Sharing }\end{array}$ & $\begin{array}{l}\text { Higher- } \\
\text { End } \\
\text { Brand }\end{array}$ & $\begin{array}{l}\text { Lower } \\
\text { End- } \\
\text { Brand } \\
\end{array}$ \\
\hline $\begin{array}{l}\text { Luxury - Volume } \\
\text { (standard deviation) }\end{array}$ & $\begin{array}{c}-4.93 \\
(13.63)\end{array}$ & $\begin{array}{c}0.18 \\
(11.45)\end{array}$ & Higher-End to Lower-End & $\begin{array}{l}-4.55 \\
(12.67)\end{array}$ & $\begin{array}{c}0.07 \\
(12.12)\end{array}$ \\
\hline \multirow[t]{2}{*}{ Volume- Economy } & $\begin{array}{c}-7.28 \\
(16.38)\end{array}$ & $\begin{array}{c}4.66 \\
(16.99)\end{array}$ & Higher-End \& Lower-End & $\begin{array}{c}-6.78 \\
(19.75)\end{array}$ & $\begin{array}{c}2.91 \\
(16.74)\end{array}$ \\
\hline & & & Lower-End to Higher-End & $\begin{array}{c}-7.39 \\
(13.03)\end{array}$ & $\begin{array}{c}4.94 \\
(15.44)\end{array}$ \\
\hline p-value & 0.01 & 0.00 & & 0.02 & 0.00 \\
\hline Shared Component & $\begin{array}{l}\text { Higher- } \\
\text { End } \\
\text { Brand }\end{array}$ & $\begin{array}{c}\text { Lower } \\
\text { End- } \\
\text { Brand }\end{array}$ & $\begin{array}{l}\text { Shared } \\
\text { Component }\end{array}$ & $\begin{array}{l}\text { Higher- } \\
\text { End } \\
\text { Brand }\end{array}$ & $\begin{array}{l}\text { Lower } \\
\text { End- } \\
\text { Brand }\end{array}$ \\
\hline Engine & $\begin{array}{c}-6.17 \\
(14.70)\end{array}$ & $\begin{array}{c}3.17 \\
(14.81)\end{array}$ & Design & $\begin{array}{c}-4.91 \\
(13.91)\end{array}$ & $\begin{array}{c}2.44 \\
(14.82)\end{array}$ \\
\hline Wiper & $\begin{array}{c}-5.40 \\
(15.21)\end{array}$ & $\begin{array}{c}2.33 \\
(14.80)\end{array}$ & Wheels & $\begin{array}{c}-7.11 \\
(16.42)\end{array}$ & $\begin{array}{c}2.36 \\
(15.11)\end{array}$ \\
\hline Interior & $\begin{array}{l}-7.45 \\
(16.36)\end{array}$ & $\begin{array}{c}2.63 \\
(15.02)\end{array}$ & Chassis/platform & $\begin{array}{c}-6.69 \\
(15.24)\end{array}$ & $\begin{array}{c}2.52 \\
(14.76)\end{array}$ \\
\hline Brakes & $\begin{array}{c}-5.99 \\
(14.87)\end{array}$ & $\begin{array}{c}2.64 \\
(15.02)\end{array}$ & Shock Absorbers & $\begin{array}{c}-5.82 \\
(15.01)\end{array}$ & $\begin{array}{c}2.96 \\
(14.51)\end{array}$ \\
\hline p-value & 0.86 & 1.00 & & & \\
\hline \multicolumn{6}{|l|}{ Brand Set } \\
\hline $\begin{array}{l}\text { Audi-Volkswagen- } \\
\text { Skoda } \\
\text { Lexus-Toyota- } \\
\text { Suzuki }\end{array}$ & $\begin{array}{c}-4.82 \\
(13.04) \\
-7.37 \\
(16.77) \\
\end{array}$ & $\begin{array}{c}1.97 \\
(13.76) \\
3.16 \\
(15.76) \\
\end{array}$ & & & \\
\hline p-value & 0.01 & 0.18 & & & \\
\hline
\end{tabular}


Table 4:

Estimation Results of Equations (3) and (4) $(\mathrm{N}=1160)$

\begin{tabular}{|c|c|c|}
\hline Variables & $\triangle \mathrm{EVA} \mathrm{HE}$ & $\triangle E$ EVAE \\
\hline LUXVOL & $-0.76^{* *}$ & $-1.39 * *$ \\
\hline (standard deviation) & $(0.31)$ & $(0.23)$ \\
\hline \multirow[t]{2}{*}{ HILOW } & $1.25 * *$ & $-3.39 * *$ \\
\hline & $(0.38)$ & $(0.29)$ \\
\hline \multirow[t]{2}{*}{ LOWHI } & $-2.10 * *$ & $1.63 * *$ \\
\hline & $(0.38)$ & $(0.29)$ \\
\hline \multirow[t]{2}{*}{$\mathrm{BS}$} & $2.95 * *$ & $-1.33 * *$ \\
\hline & $(0.32)$ & $(0.23)$ \\
\hline \multirow[t]{2}{*}{ ENGINE } & -0.77 & $0.84 *$ \\
\hline & $(0.55)$ & $(0.43)$ \\
\hline \multirow[t]{2}{*}{ INTERIOR } & $-2.06 * *$ & 0.07 \\
\hline & $(0.61)$ & $(0.41)$ \\
\hline \multirow[t]{2}{*}{ BRAKES } & -0.59 & 0.31 \\
\hline & $(0.61)$ & $(0.44)$ \\
\hline \multirow[t]{2}{*}{ DESIGN } & 0.49 & 0.11 \\
\hline & $(0.57)$ & $(0.39)$ \\
\hline \multirow[t]{2}{*}{ WHEELS } & $-1.72 *$ & 0.03 \\
\hline & $(0.63)$ & $(0.44)$ \\
\hline \multirow[t]{2}{*}{ SHOCK ABSORBERS } & -0.42 & 0.19 \\
\hline & $(0.61)$ & $(0.46)$ \\
\hline \multirow[t]{2}{*}{ CHASSIS } & $-1.28 *$ & 0.19 \\
\hline & $(0.59)$ & $(0.44)$ \\
\hline \multirow{2}{*}{$\mathrm{EVA}_{\text {he }}$} & $-0.51 * *$ & $0.46^{* *}$ \\
\hline & $(0.01)$ & $(0.01)$ \\
\hline \multirow{2}{*}{$\mathrm{EVA}_{\mathrm{le}}$} & $0.44 * *$ & $-0.47 * *$ \\
\hline & $(0.01)$ & $(0.01)$ \\
\hline \multirow[t]{2}{*}{ AGE } & $-0.11 * *$ & $-0.17 * *$ \\
\hline & $(0.02)$ & $(0.02)$ \\
\hline \multirow[t]{2}{*}{ SEX } & $0.97 * *$ & 0.45 \\
\hline & $(0.37)$ & $(0.26)$ \\
\hline \multirow[t]{2}{*}{ EDUC } & $1.89 * *$ & $1.00 * *$ \\
\hline & $(0.24)$ & $(0.29)$ \\
\hline \multirow[t]{2}{*}{ INCOME } & $-2.97 * *$ & $1.03 * *$ \\
\hline & $(0.42)$ & $(0.29)$ \\
\hline \multirow[t]{2}{*}{ EXPERIENCE } & 0.02 & $0.15 * *$ \\
\hline & $(0.02)$ & $(0.01)$ \\
\hline \multirow[t]{2}{*}{ OWNLUX } & $-7.56^{* *}$ & $-8.07 * *$ \\
\hline & $(0.85)$ & $(0.60)$ \\
\hline \multirow[t]{2}{*}{ OWNVOL } & $-8.56 * *$ & $3.24 * *$ \\
\hline & $(0.46)$ & $(0.33)$ \\
\hline \multirow[t]{2}{*}{ OWNECON } & $8.74 * *$ & $2.68 * *$ \\
\hline & $(0.98)$ & $(0.74)$ \\
\hline \multirow[t]{2}{*}{ CONSTANT } & $8.65 * *$ & -0.83 \\
\hline & $(1.80)$ & $(1.16)$ \\
\hline \multirow[t]{2}{*}{ S.D. CONSTANT } & $9.34 * *$ & $10.33 * *$ \\
\hline & $(0.14)$ & $(0.10)$ \\
\hline Loglikelihood RE & -4098.61 & -4542.76 \\
\hline Loglikelihood OLS & -4469.68 & -3786.33 \\
\hline p-value Likelihood-ratio (RE-OLS) test & 0.00 & 0.00 \\
\hline
\end{tabular}


Table 5:

Estimation Results of Regression Model on Effect of Component Sharing on Brand Market Share (in bold: coefficient estimates significantly different from 0 at the $5 \%$ significance level)

\begin{tabular}{|c|c|c|c|c|}
\hline & \multicolumn{2}{|c|}{ Market Share } & \multicolumn{2}{|c|}{ Market Share Change } \\
\hline & Audi & Volkswagen & Seat & Skoda \\
\hline Lagged share & 0.23 & 0.39 & -0.48 & -0.51 \\
\hline Price Change (1000 Euro) & -0.10 & -0.28 & 0.01 & -0.01 \\
\hline Model Change 1 & 0.38 & 0.18 & 0.27 & 0.16 \\
\hline Model Change 2 & 0.21 & & & \\
\hline Component sharing & & & & \\
\hline - Audi to Volkswagen & 0.15 & 0.23 & & \\
\hline - Audi to Skoda & -0.10 & & & 0.12 \\
\hline - Audi to Seat & -0.27 & & 0.45 & \\
\hline - Seat to VW & & 0.74 & -0.19 & \\
\hline - Skoda to VW & & $-0.82^{a}$ & & 0.45 \\
\hline $\mathrm{R}^{2}$ & 0.77 & 0.65 & 0.59 & 0.68 \\
\hline F-value & 13.66 & 8.37 & 7.04 & 10.37 \\
\hline Durbin-Watson & 1.91 & 1.76 & 2.02 & 2.26 \\
\hline
\end{tabular}

\footnotetext{
a significantly different from zero at the $10 \%$ significance level
} 